\title{
Georges Cuisenaire's numbers in colour. A teaching aid that survived the 1950s
}

Dirk De Bock

KU Leuven, Belgium

\begin{abstract}
In 1952, a Belgian primary school teacher, Georges Cuisenaire, published Les nombres en couleurs, a booklet in which the author describes his invention and explains a corresponding method for teaching elementary arithmetic. Cuisenaire materialized the numbers from one to ten by means of rods of corresponding lengths and in different colours. The rods provided a concrete tool for exploring and gaining insight in basic concepts and skills, such as the four basic operations, finding divisors and multiples, working with fractions, the decimal system, arithmetic sequences, and area and volume calculation. From the mid-1950s, with the support of Caleb Gattegno, the Cuisenaire rods broke through worldwide. In subsequent years, empirical research into the effectiveness of the Cuisenaire's method was initiated and in several countries Cuisenaire Associations were founded. In the late 1960s and 1970s, a number of attempts were made to use the material for the teaching of typical modern mathematics contents to (very) young children, but the use of the rods in this context was sometimes far-fetched and did not break through.
\end{abstract}

Keywords: CIEAEM, Cuisenaire rods, numbers in colour, teaching aid, teaching material, Georges Cuisenaire, Caleb Gattegno

\section{Introduction}

A main topic of debate in circles of mathematics education during the 1950s, in particular within the Commission Internationale pour l'Étude et l'Amélioration de l'Enseignement des Mathématiques (CIEAEM)/International Commission for the Study and Improvement of Mathematics Teaching, was the use of concrete models, teaching materials or teaching aids (Bernet \& Jaquet, 1998; Gattegno et al., 1958). One of the teaching materials that became really successful during that period was the set of Cuisenaire rods (in French: réglettes), a set of coloured blocks - originally in wood and hand-painted - with a side face of $1 \mathrm{~cm}^{2}$ and with lengths increasing from 1 to $10 \mathrm{~cm}$, symbolizing the natural numbers from 1 to 10 (fig. 1). Rods of different lengths were painted in different colours, but rods symbolizing related numbers, such as 5 and 10, were painted in related colours (in this case, yellow and orange), while rods symbolizing unrelated numbers, such as 5 and 9 , were painted in completely different colours (in this case, yellow and blue). Boxes with a sufficient number of rods of each colour were provided for students' personal use, together with similarly coloured cardboard material (called product cards). The rods were originally devised and utilized to explore and to gain insight into elementary mathematical concepts and skills, such as the four basic operations, finding divisors and multiples, working with fractions, the decimal system, arithmetic sequences, and area and volume calculation. This structured material Barbin, E., Bjarnadóttir, K., Furinghetti, F., Karp, A., Moussard G., A., Prytz, J., \& Schubring, G. (Eds.) (2020). "Dig where you stand" 6. Proceedings of the sixth International Conference on the History of Mathematics Education. Münster: WTM-Verlag. 
was invented by a Belgian primary school teacher, Georges Cuisenaire, who also developed a corresponding method for teaching elementary arithmetic. We first briefly outline Cuisenaire's biography.
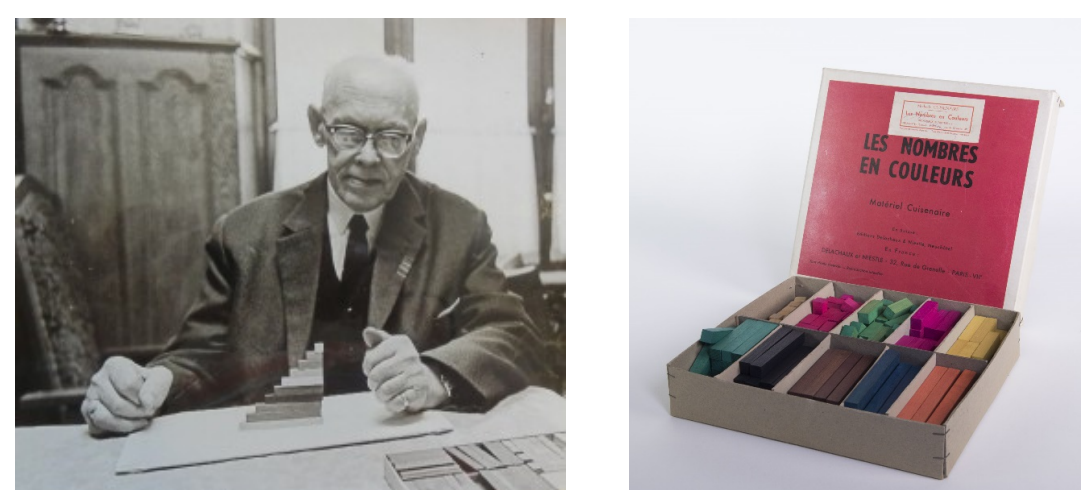

Fig. 1. Left: Georges Cuisenaire with his famous rods, ca. 1965. Right: Box with Cuisenaire rods, French-Swiss edition by Delachaux, mid-1950s (collection Y. Cuisenaire)

\section{Georges Cuisenaire}

Emile-Georges Cuisenaire was born in Quaregnon, a municipality in the Belgian province of Hainaut on September 7, 1891 and died on January 1, 1976 in Thuin, also a municipality in Hainaut. In 1911, Cuisenaire graduated as a primary school teacher at the École Normale de l'État [Teachers' College of the State] in Mons. In the meantime, he had studied at the Conservatoire [School of Music] in Mons, where he was awarded several first prizes (Festraets-Hamoir, 2001). In 1911, Cuisenaire started his career as a teacher in a primary school in Thuin. In 1919, after the First World War, in which he served as a volunteer, he became director of a primary school, also situated in Thuin, and in 1934 he was appointed general director of municipal education in Thuin. In 1948, he founded the École Industrielle [Industrial School] in Thuin, of which he became the director until his retirement in 1957.

Cuisenaire became soon very interested in the pedagogy of primary education, in particular in Ovide Decroly's new education or reform pedagogy. Decroly was an exponent of an international educational movement that flourished in Belgium in the period before the Second World War and had led in 1936 to new curricula for the primary level, putting a strong emphasis on child-centeredness, on active learning processes, and on connecting school matter with children's concrete, daily-life experiences (Ministerie van Openbaar Onderwijs, 1936). During the 1930s, Cuisenaire published a number of teaching materials for primary school, including lesson-walks and didactic cahiers on environment and climate, which were undeniably influenced by Decroly's pedagogical principles.

In subsequent years, Cuisenaire concentrated on the learning of mathematics. After some years of experimentation with children, among others with coloured 
strips in cardboard, in 1951 Cuisenaire registered and "commercialized" his numbers in colour in their final form and from then on, they were distributed among the community of Belgian primary school teachers (Jeronnez, 1976). Les nombres en couleurs. Nouvean procédé de calcul active applicable à tous les degrés de l'école primaire [Numbers in colour. New active calculation procedure applicable at all levels of primary school], a booklet for teachers in which the author describes his invention and explains a corresponding method for teaching elementary arithmetic in the different grades of primary education was published one year later (Cuisenaire, 1952). Cuisenaire was not the first to develop concrete materials to support children in learning arithmetic. Already in the 1920s, the Swiss Mina Audemars and Louise Lafendel had invented a 66-block method for learning children to count (Jeronnez, 1976) and from the late 1940s in the US, Catherine Stern was experimenting with structural materials in arithmetic (experiments that Cuisenaire most probably didn't know at the time). What made Cuisenaire's method unique is likely the well-thought-out colour-coding system. Cuisenaire's schooling as a musician inspired him to develop that system.

Since the RELATIONSHIP OF SOUNDS depends on proportional lengths and determines FAMILIES OF SOUNDS [...] and colours also have scientifically established wavelengths, why should there not be FAMILIES OF COLOURS that obey RELATIONSHIPS OF COLOURS similar to those of sounds. (Cuisenaire, 1961, p. 11, capital letters by Cuisenaire)

The families of colours to which Cuisenaire refers, are the "red family" (red, purple and brown, representing 2, 4 and 8 respectively), the "green-blue" family (light green, dark green and blue, representing 3, 6 and 9 respectively) and the "yellow family" (yellow and orange, representing 5 and 10 respectively). The rods representing 1 and 7 were painted in white and black respectively. Together with the length of the rod, this colour-coding system was intended to facilitate the child's familiarity with the number. Cuisenaire explained the power of his method as follows:

Thus, the method of the numbers in colour:

- Puts each child back into the conditions of the beginning and forces each one to reconstruct arithmetic for his own purpose at a rhythm which varies and depends on the very unequal possibilities of each human being in development.

- Creates visual, muscular and tactile images that are clear, precise and sustainable.

- Preserves a global and pure acquisition of the number concept during various compositions and decompositions, invented and verified by means of immutable, faithful and interrelated schemes.

- Gradually leads the child to the complex of abstraction by accustoming him to see mentally a countless number of cases.

- By the materialization of his calculational thinking, materialization translated by his numerous manipulations with the active intervention of all bis senses, which constructively associates colours and dimensions, the child develops his analytical mind by realizing his calculations drawn 
from his own experience. The child is led without restraint to objectivity and to a more accurate adaptation of his whole psyche.

- Makes calculation sensory, attractive, lively and saves time, while simplifying the task of the teacher.

- Bridges the gap between the acquisitions made during the exercises of observation and the necessary systematization. (Cuisenaire, 1952, pp. 17-18, italics by Cuisenaire)

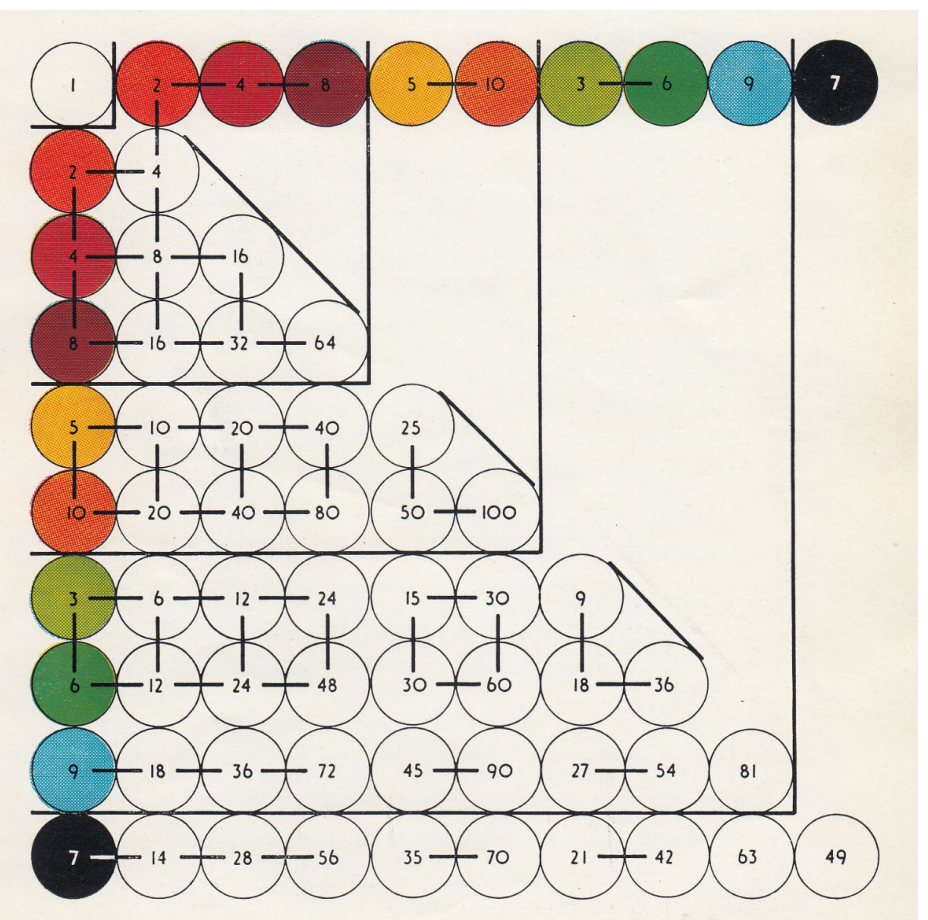

Fig. 2. Theoretical chart showing the products by families and their mutual relationships (third edition (1961) of Cuisenaire and Gattegno (1954), no pagination, collection of the National Library of Education Copenhagen)

\section{Caleb Gattegno and the international breakthrough of the rods}

Despite support from Ernest Natalis (1897-1974), a professor at the Institut de Psychologie et des Sciences de l'Éducation of the Université de Liège (Natalis, 1954) and from V. Jacquemin, a primary school inspector from the Thuin region who had been following Cuisenaire's experiments from the beginning, Cuisenaire's invention was initially not welcomed with great enthusiasm among Belgian primary school teachers and their authorities - some were even opposed to it, maybe because they did not see the didactical potential of the new material (Jeronnez, 1954-1955, 1976; Savary, 1965).

However, the Cuisenaire rods did not have to wait long for an international breakthrough. In 1953, during a lecture tour in Belgium, Caleb Gattegno (1911- 
1988), mathematician and psychologist at the University of London and secretary of the CIEAEM, was alerted about the rods by Fernand Hotyat (1896-1975), a prominent Belgian school psychologist and at that time the director of the Institut Supérieur de Pédagogie du Hainaut (Gattegno, 1988; Roller, 1964, 1966). Gattegno visited Cuisenaire in his school in Thuin, became acquainted with the material and was immediately enthusiastic: "Now it is no longer a matter of finding a way to improve education. It has been found by Cuisenaire" (Gattegno, 1954-1955, p. 21). In Mathematica \& Paedagogia, the journal of the Belgian Society of Mathematics Teachers, he praised the material in a lyrical, fairy-tale style:

Once, there was a primary school teacher whose knowledge of mathematics did not exceed that of other teachers, but who loved his pupils so much that he asked himself what he should do to make the compulsory study of arithmetic look easy to them and give them joy. Where would he find the answer to his question? To consult mathematicians is useless. They do not understand the difficulties children are faced with. Similarly, it does not seem that the aid of psychologists will help us more because their knowledge about what a child can do is much separated from the educational system which determines the child $[\ldots]$ The land, in truth, was a virgin and was missing a brand new idea that would shed new light on the problem. Georges Cuisenaire, primary school teacher in Thuin, did find that idea in the art of music he was always practicing. (Gattegno, 1954-1955, p. 17)

Gattegno's visit to Thuin proved to be a turning point in the history of the rods which from then on would gradually but with great success conquer the primary mathematics classrooms throughout the world (Gattegno, 1953; Gattegno, 1954; Gattegno, 1954-1955; Cuisenaire \& Gattegno, 1954). Even Marshall Stone, president of the International Commission on Mathematical Instruction and of the International Union of Mathematicians, in his introductory address to the Royaumont Seminar (1959) pointed to the success of Cuisenaire's method of making mathematics lively and interesting for young children (OEEC, 1961).

Gattegno's discovery of the rods was also a turning point in his own thinking: "before I met [Cuisenaire] my own thinking led only to variations of classical themes in the field of number learning" (Gattegno, 1960, p. 1), as well as in his professional career: Gattegno gradually resigned from his responsibilities at the University of London to become a worldwide ambassador of the Cuisenaire rods (Servais, 1959). Already in 1954, Gattegno established the first Cuisenaire Company in Wembley (UK) to distribute the material (Powell, 2007) and, together with Cuisenaire, he published in English Numbers in colour (Cuisenaire \& Gattegno, 1954). In the Preface to that book, Gattegno articulated his view: The importance of Cuisenaire's discovery can be formulated in mathematical and psychological terms. Mathematically he has created a material that can exemplify all the arithmetical relationships met with in school life, so that we have an aide which is adequate at every stage, when we pass from counting to multiplication, from addition to fractions or to proportion, for we have a set of rods that can be "structured" in a variety of ways according to the particular relation that is in question $[\ldots]$ 
Psychologically, the value of Cuisenaire's contribution lies in the fact that by providing a semi-abstract material he has overcome the obstacle of the gap between active and intellectual thought. Our minds are swift when dealing with images and representations but they move slowly in the actual performance of an action. (Cuisenaire \& Gattegno, 1954, pp. v-vi)

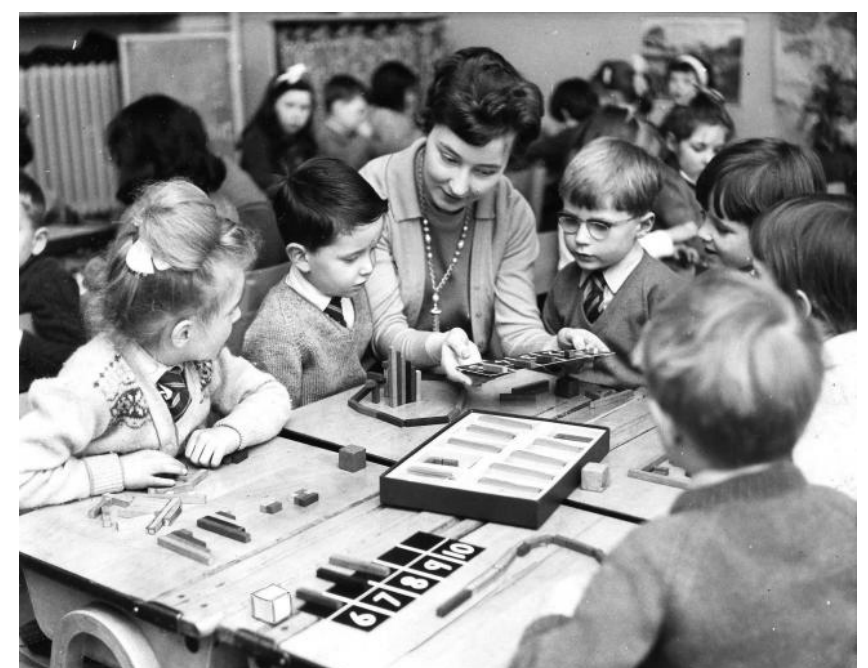

Fig. 3. Pupils are shown how to use the Cuisenaire rods at St Charles' Primary in North Kelvinside, Glasgow, 1965 (Herald Picture Archive)

According to Gattegno, the Cuisenaire rods not only provided learners with a concrete model for the study of arithmetic, but also with a tool for active manipulation with which they could first, for a sufficiently long period, investigate mathematical relations for themselves in a "qualitative" way (Gattegno, 1955-1956). Rather than on the act of counting, Gattegno based his experimental teaching of arithmetic on the perception of length and colour, and on the recognition of relations of equivalence (equality) and order (inequality) in sets of rods "with the eyes or by touch" to equip students with the mental structures on which "numerical" arithmetic is based: "Colour and length offer information that is perceivable and its translation into numerical language gives the latter the dynamics which is far less apparent when notation is used" (Gattegno, 1956, p. 87).

Gattegno considered the Cuisenaire rods as a full algebraic model in the mathematical sense (isomorphic to that of the positive rationals, if the existence of an infinite number of rods is assumed), but more than that. By letting children manipulate and "have a dialogue" with the rods, for instance about equivalences and inequalities by using the rods' colour names, it would allow them to experience (structures of) algebra before arithmetic, a position that, however, was not generally accepted: "Not all have managed to see the tremendous power that results from the recasting of the teaching of elementary mathematics by 
providing 'receptacles' of algebra before more structured arithmetical facts are verbalized" (Gattegno, 1987, p. 26).

\section{The rods and the upcoming empirical research}

From the second half of the 1950s, empirical research into the effectiveness of the Cuisenaire-Gattegno method (Cuisenaire \& Gattegno, 1954) started. In a study from 1956 under everyday classroom conditions, 31 British teachers who had used the approach were interviewed. They reported favorable results, both in terms of children's interest, self-confidence and motivation, and on account of the insights in arithmetic they had gained (Howard, 1957). The author of the study added some general conclusions drawn from the interviews and from his observation of classroom activities and demonstrations:

- The Cuisenaire-Gattegno colour approach to arithmetic has been used by experienced teachers to their satisfaction. There was general agreement that the approach was valuable and held promise for future development through experimentation.

- While some benefits were available for slower pupils, the average and brighter pupils seemed to benefit particularly by the teachers' use of the approach.

- The consensus of opinion of the teachers interviewed was that certain mathematical concepts that are not usually developed easily in children by current approaches to arithmetic were facilitated considerably by the use of the material in the recommended manner.

- At present the Cuisenaire-Gattegno approach holds considerable promise as a supplement to current methods, and further studies should be made to evaluate its effectiveness and to develop the procedures. (Howard, 1957, p. 192)

Howard's call for further studies was answered by several American researchers during the 1960s who compared the effectiveness of Cuisenaire-Gattegno approach with some traditional ways of teaching arithmetic with material aids in an empirically controlled setting. A summary of some of these studies was provided by Fennema (1972). Typically, the results showed that the Cuisenaire method was more effective for younger students, while the results with older students were sometimes more ambiguous. Also large-scale research in Québec (Canada) by Madelaine Goutard did not provide a clear picture: Although students in Cuisenaire classes were ahead on a special Cuisenaire test, they were behind on problems and they did not perform significantly better on mechanical arithmetical performance (Deans, 1972; Goutard, 1964). It did however not undermine the researcher's belief in the method: "Because they [students in Cuisenaire classes] have entered an open pedagogy, these classes now have a future in front of them, a future that I see immensely" (Goutard, 1965, p. 6).

Whatever the results of empirical research, the charismatic Gattegno always managed to find Cuisenaire enthusiasts in dozens of countries, including Australia, Belgium, Canada, France, Germany, Spain, Switzerland, the UK and the US, and in 1975, already more than one million sets of rods were sold 
worldwide (Festraets-Hamoir, 2001). In several of these countries, Cuisenaire Associations were founded. In 1966, the Association Cuisenaire Belgique [Belgian Cuisenaire Association] even created a prestigious annual prize, the réglette d'or [golden rod] - the rod representing 10 in massive gold - to reward a work, a study or a thesis on Cuisenaire's method (La réglette d'or, 1967). In Belgium, the circle of Cuisenaire enthusiasts included, among others, the aforementioned professor Natalis and inspector Jacquemin, as well as the university educated mathematics teachers Louis Jeronnez, editor of the Bulletin of the Association Cuisenaire Belgique (Association Cuisenaire Belgique, 1989), Lucien Delmotte, Willy Servais, and professor Georges Papy, figurehead of the modern mathematics movement in Belgium.

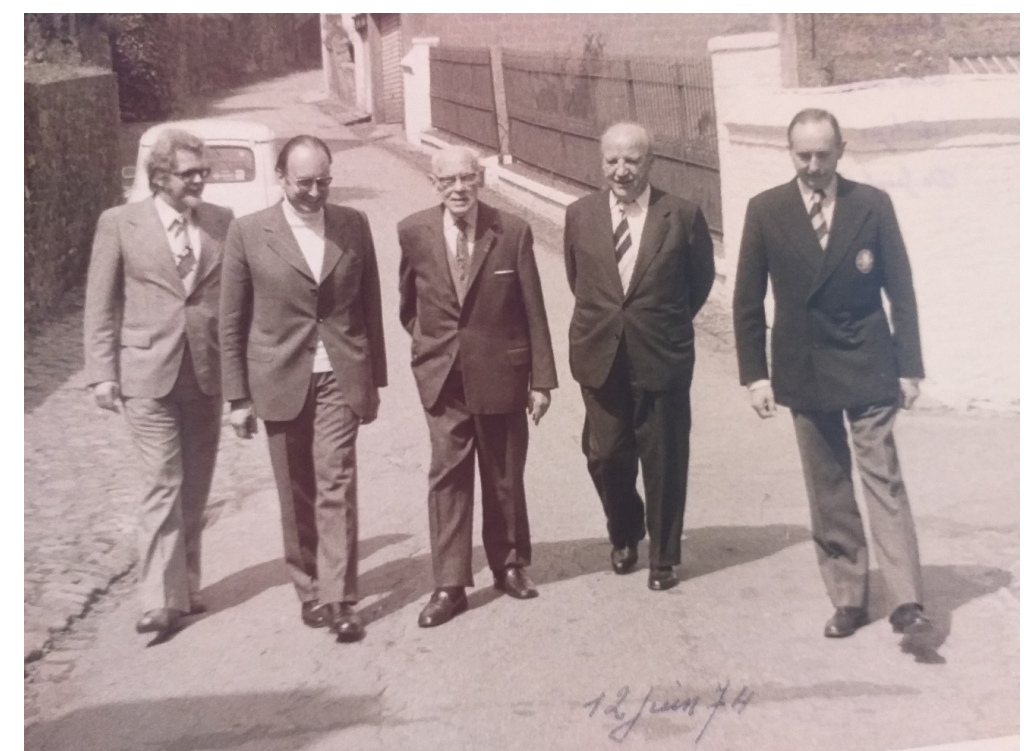

Fig. 4. In front of Georges Cuisenaire's house in Thuin, 1974 (collection of the Cuisenaire family). From left to right: Marcel Gross (Swiss education officer), Léo Biollaz (Swiss pedagogue and winner of the réglette d'or 1967), Georges Cuisenaire, Franz Schubiger (German publisher), Jean De Groef (Belgian publisher and secretary of Association Cuisenaire Belgique)

\section{Cuisenaire rods and modern mathematics}

Papy considered Cuisenaire's invention as "one of the great discoveries in the history of mathematics education" (Papy, 1966, p. 4) and regarded his own approach with multi-coloured graphs for introducing modern mathematics at the secondary level (De Bock, Roelens, \& Vanpaemel, 2019) as a continuation of Cuisenaire's method. Later, in collaboration with his wife Frédérique, Papy will develop the minicomputer, a kind of abacus to help young children to acquire an understanding of the numeration system and a thorough knowledge of the basic operations of counting, addition and subtraction in a concrete and playful way 
(G. Papy, 1968). Papy's minicomputer consisted of plates, arranged according to the decimal system and these plates were subdivided into four square sections for calculating in the binary system. Papy coloured these sections according to the colour-coding system of the Cuisenaire rods (white, red, purple and brown the last three colours belonging to the "red family" - corresponding respectively to the numerical values $1,2,4$ and 8 , or $10,20,40$ and 80 , and so on) "to make the four rules of the machine easily accessible" (Papy, 1970, p. 40). In spite of its ingenuity, Papy's minicomputer did not penetrate primary schools on a large scale. Minicomputer and the Cuisenaire rods, together with Dienes' logiblocks, however, still played an important role for creating didactic situations in the experimental classes of Frédérique in the late 1960s and early 1970s, which were intended to prepare for the modern mathematics reform at primary school level.

Thanks to the Cuisenaire material, students classify, order, build trains and walls, establish one-to-one relations and pay special attention to the binary family of red rods. (Frédérique, 1970, p. x)
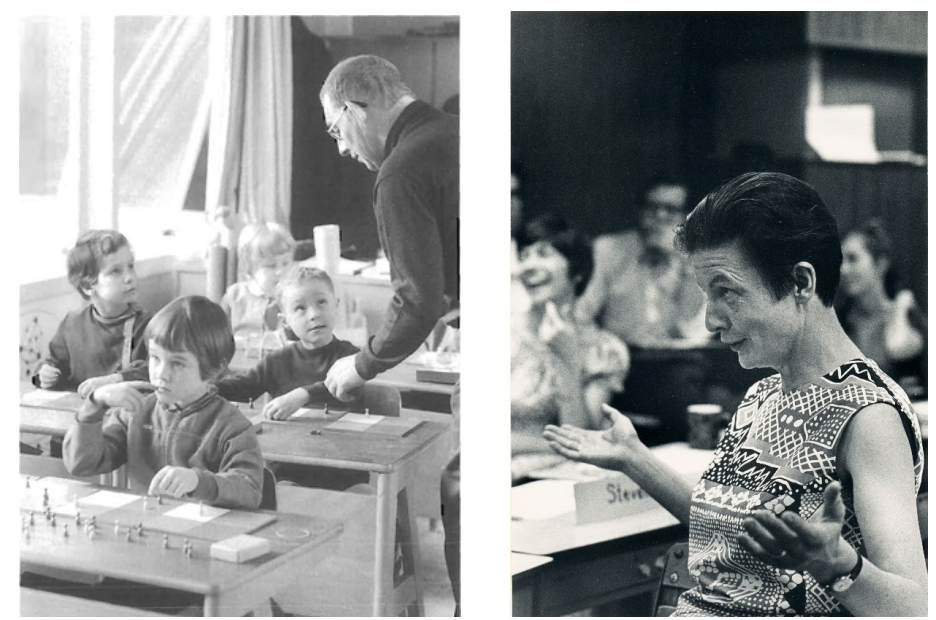

Fig. 5. Left: Georges Papy experimenting with minicomputer in a Brussels primary school, late 1960s (Persagentschap Belga). Right: Frédérique Papy, mid-1970s (collection R. Kennes)

In the late 1960s and early 1970s, several other attempts were made in Belgium and elsewhere to use the Cuisenaire rods for teaching typical modern mathematics content to children, such as the basic notions of set theory, including the set operations and the study of relations, the commutative, associative and distributive properties of addition and multiplication, the calculation in number bases other than 10, modular arithmetic and even the formation of the group concept (see, e.g., Jeronnez, 1966a, 1966b; F. Papy, 1968; Rollin, 1971; Vandendriessche, Vandendriessche, Cousin, Dumont, \& Level, 1967). The experiment that undoubtedly had the strongest impact on educational practice in Belgium was the so-called Waterloo experiment, conducted in the 
Athénée Royal de Waterloo [Royal Athenaeum of Waterloo] and led by Louis Jeronnez (Jeronnez, 1968; Jeronnez \& Lejeune, 1970, 1972a, 1972b). The promotors strongly believed in a modern pedagogy based on the Cuisenaire rods.

The new teaching of mathematics, even if it seems difficult to us, is very attractive to our children who love to overcome difficulties and enjoy themselves in a certain abstraction. They form sets, make inclusions and experience great joy in reflecting on mathematical situations taken from class life or generated through structured materials.

Our children will therefore reject the use of outdated methods and materials such as capsules, buttons, pawns, etc. to learn to calculate.

Here again, we must give them a structured material that can satisfy their need to reflect and create: The Cuisenaire material is therefore irreplaceable. (Jeronnez \& Lejeune, 1972b, p. 38)

Although this pedagogy primarily focused on abstraction, problem solving was not neglected. We illustrate this with an assignment in arithmetic that was intended to be solved using the rods.

Bruno met his friends and they played all afternoon in the garden. The shop on the corner sells lollipops for 3 francs and chocolates for 4 francs. Bruno would like to buy some with the 28 francs he received from his mother. What can he buy? [...]

The children realize that there are several possibilities and try to find as many solutions as possible by forming a 28 carpet with the $v$ and $\mathrm{R}$ rods [which represent, respectively, the numbers 3 and 4].

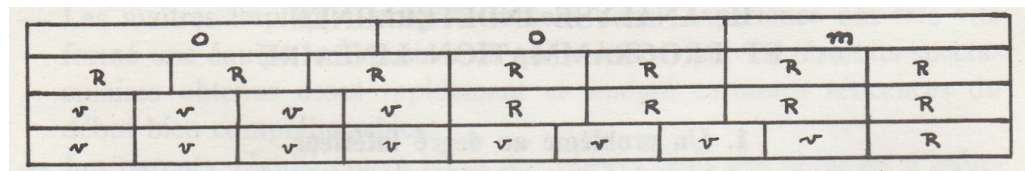

Looking at their carpets, the children discover that Bruno can buy 7 chocolates (they write: $7 \times 4=28$ ) or 4 lollipops and 4 chocolates (they write: $4 \times 3+4 \times 4=28$ ) or else 8 lollipops and 1 chocolate (they write: $8 \times 3+1 \times 4=28$ ). (Jeronnez \& Lejeune, 1972a, pp. 71-72)

However, applications of the rods in a modern mathematics pedagogy were often far-fetched and did not break through on a large scale. More generally, modern mathematics in Belgium quickly failed, especially at the primary level (De Bock \& Vanpaemel, 2019). 


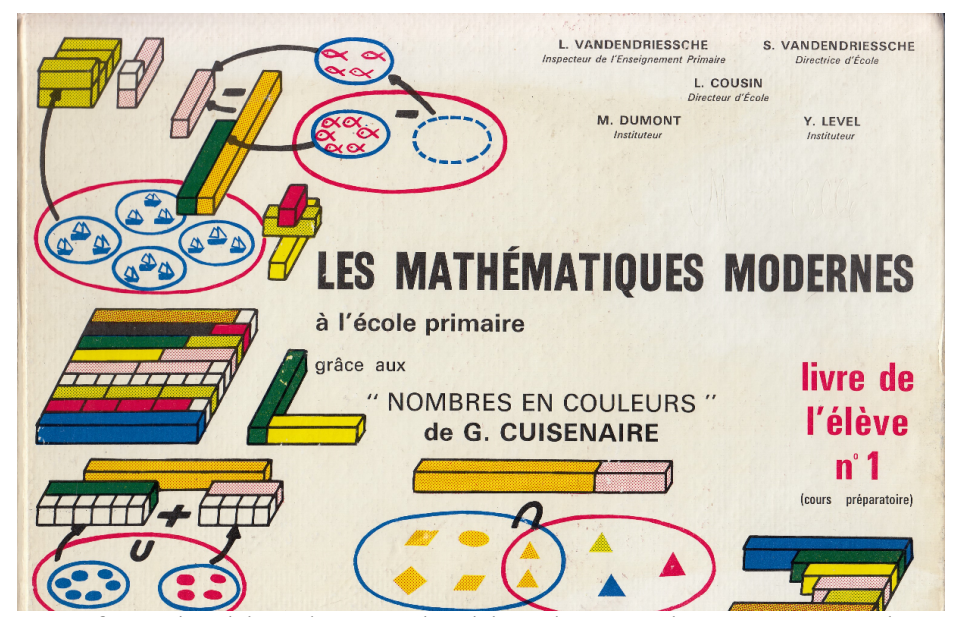

Fig. 6. Cover of Vandendriessche, Vandendriessche, Cousin, Dumont, and Level (1967) (author's collection)

\section{Epilogue}

Cuisenaire's coloured rods, a structured material to teach arithmetic, had its glory days during the 1950s, 1960s and early 1970s. From the mid-1970s onwards, in a number of countries including Belgium, modern mathematics was introduced in primary schools. It overwhelmed both teachers and authorities (Jeronnez, 1976). Several attempts were made to use the Cuisenaire rods to teach typical modern mathematics content, but modern mathematics quickly failed and, at least in Belgium, a period of disenchantment for the rods followed.

Also from the second half of the 1970s, Georges Cuisenaire, who had promoted the dissemination of his method until his decease in 1976, could no longer put his brainchild on the international agenda. However, the many internet sites that today refer to the Cuisenaire rods show that his method did not lose interest in specific educational circles all over the globe. In particular, recent publications of the Association of Teachers of Mathematics (Association of Teachers of Mathematics, 2017; Küchemann, 2019; Mathematics with Cuisenaire rods, 2017) and by Georges Cuisenaire's grandson Yves ("Bienvenue sur Cuisenaire.eu”, n.d.; Cuisenaire, 2019; Cuisenaire \& Guissard, 2019) have shown that the material offers a wide range of didactical possibilities for contemporary mathematical education.

Note. All translations were made by the author. Acknowledgement. The author thanks Leo Rogers for his feedback on an earlier draft of this paper. 


\section{References}

Association Cuisenaire Belgique. (1989). Compte-rendus des conférences de l'Association Cuisenaire Belgique [Reports of the conferences of the Belgian Cuisenaire Association]. Mathématique et Pédagogie, 74, 35-38.

Association of Teachers of Mathematics. (2017). Cuisenaire-From early age to adult. Derby: ATM.

Bernet, Théo, \& Jaquet, François (1998). La CIEAEM au travers de ses 50 premières rencontres [CIEAEM through its first 50 meetings]. Neuchâtel: CIEAEM.

Bienvenue sur Cuisenaire.eu [Welcome to Cuisenaire.eu]. (n.d.). Retrieved September 25, 2019, from cuisenaire.eu.

Cuisenaire, Georges (1952). Les nombres en couleurs. Nouvean procédé de calcul par la méthode active, applicable à tous les degrés de l'école primaire [Numbers in colour. New method of calculation by the active method, applicable to all grades of primary school]. Tamines: Duculot-Roulin.

Cuisenaire, Georges (1961). Historique des recherches concernant les nombres en couleurs [History of research on the numbers in colour], typewritten text reproduced by the Maison de l'Imprimerie in Thuin, 2013.

Cuisenaire, Georges, \& Gattegno, Caleb (1954). Numbers in colour: A new method of teaching arithmetic in primary schools. London: Heinemann.

Cuisenaire, Yves (2019). Du calcul et des maths. Calcul et approche mathématique avec les nombres en couleur [Calculation and math. Calculation and mathematical approach with the numbers in colour]. Aix-en-Provence: Bookelis.

Cuisenaire, Yves, \& Guissard, Marie-France (2019). Regards sur un article: les réglettes "Cuisenaire» pour résoudre des problèmes [Looking at an article: the Cuisenaire rods to solve problems]. Losanges, 44, 68.

Deans, John F. (1972). Structural apparatus. In L. R. Chapman (Ed.), The process of learning mathematics (pp. 254-270). Oxford: Pergamon Press.

De Bock, Dirk, Roelens, Michel, \& Vanpaemel, Geert (2019). Mathématique moderne: A pioneering Belgian textbook series shaping the New Math reform of the 1960s. In K. Bjarnadóttir, F. Furinghetti, J. Krüger, J. Prytz, G. Schubring, \& H. J. Smid (Eds.), "Dig where you stand" 5. Proceedings of the Fifth International Conference on the History of Mathematics Education (pp. 129-145). Utrecht: Freudenthal Institute.

De Bock, Dirk \& Vanpaemel, Geert (2019). Rods, sets and arrows: The rise and fall of modern mathematics in Belgium. Cham: Springer.

Fennema, Elizabeth H. (1972). Models and mathematics. The Arithmetic Teacher, 19 (8), 635-640.

Festraets-Hamoir, Claudine (2001). Cuisenaire. In Nouvelle biographie nationale [New national biography] (vol. 6, pp. 93-94). Brussels: Académie Royale des Sciences, des Lettres et des Beaux-Arts de Belgique.

Frédérique. (1970). Les enfants et la mathématique 1 [Children and mathematics 1]. Brussels, Montréal, Paris: Marcel Didier.

Gattegno, Caleb (1953). Numbers in colour. Bulletin of the Association for Teaching Aids in Mathematics, 2.

Gattegno, Caleb (1954). Les nombres en couleurs de Cuisenaire [Numbers in colour by Cuisenaire]. Moniteur des Instituteurs et des Institutrices Primaires, 72 (11), 162-163.

Gattegno, Caleb (1954-1955). Les nombres en couleurs de Georges Cuisenaire [Numbers in colour by Georges Cuisenaire]. Mathematica \& Paedagogia, 4, 17-22. 
Gattegno, Caleb (1955-1956). Remarques théoriques sur le matériel Cuisenaire [Theoretical remarks on the Cuisenaire material]. Mathematica \& Paedagogia, 9, 30-36.

Gattegno, Caleb (1956). New developments in arithmetic teaching in Britain: Introducing the concept of "set". The Arithmetic Teacher, 3 (3), 85-89.

Gattegno, Caleb (1960). Modern mathematics with numbers in colour. Reading, UK: Educational Explorers.

Gattegno, Caleb (1987). Parts and wholes. Mathematics Teaching, 119, 26-27.

Gattegno, Caleb (1988). Reflections on forty years of work on mathematics teaching. For the Learning of Mathematics, 8 (3), 41-42.

Gattegno, Caleb, Servais, Willy, Castelnuovo, Emma, Nicolet, Jean-Louis, Fletcher, Trevor J., Motard, Lucien, Campedelli, Luigi, Biguenet, Alphonse, Peskett, Jack W., \& Puig Adam, Pedro (1958). Le matériel pour l'enseignement des mathématiques [Materials for the teaching of mathematics]. Neuchâtel: Delachaux et Niestlé.

Goutard, Madelaine (1964). Mathematics and children. Reading, UK: Educational Explorers.

Goutard, Madelaine (1965). Cet enchantement si particulier [This magic so special]. Les Nombres en Couleurs. Bulletin Cuisenaire, 17-18, 2-6.

Howard, Charles F. (1957). British teachers' reactions to the Cuisenaire-Gattegno materials: The colour-rod approach to arithmetic. The Arithmetic Teacher, 4 (5), 191 195.

Jeronnez, Louis (1954-1955). Sur les nombres en couleurs [About the numbers in colour]. Mathematica \& Paedagogia, 6, 39.

Jeronnez, Louis (1966a). Les nombres en couleurs à l'heure de la mathématique moderne [Numbers in colour at the time of modern mathematics]. In Journées d'études 45: Nombres en couleurs [Study days 45: Numbers in colour] (pp. 15-27). Brussels: Ministère de l'éducation nationale et de la culture, Organisation des études, Méthodes, stages de formation et de perfectionnement du personnel et matériel didactique.

Jeronnez, Louis (1966b). Mathématique moderne et réglettes Cuisenaire [Modern mathematics and Cuisenaire rods]. Les Nombres en Couleurs. Bulletin Cuisenaire, 24, 1-5.

Jeronnez, Louis (1968). Mathématique moderne à l'école primaire et les réglettes Cuisenaire [Modern mathematics in primary school and the Cuisenaire rods]. Brussels: Calozet.

Jeronnez, Louis (1976). Hommage à Georges Cuisenaire [Tribute to Georges Cuisenaire]. Mathématique et Pédagogie, 6, 75-81.

Jeronnez, Louis, \& Lejeune, Isabelle (1970). À la découverte de la mathématique et les réglettes Cuisenaire [Discovering mathematics and the Cuisenaire rods]. Brussels : Calozet.

Jeronnez, Louis, \& Lejeune, Isabelle (1972a). L'expérience de Waterloo d'un enseignement moderne de la mathématique à l'école primaire [The Waterloo experiment on a modern teaching of mathematics in primary school]. Mathematica \& Paedagogia, 53-54, 69-80.

Jeronnez, Louis, \& Lejeune, Isabelle (1972b). Les réglettes Cuisenaire et la mathématique moderne [The Cuisenaire rods and modern mathematics]. Math-École, 50-51, 30-38.

Küchemann, Dietmar (2019). Cuisenaire rods and symbolic algebra. Mathematics Teaching, 265, 34-37.

La réglette d'or. (1967). Math-École, 27, 4.

Mathematics with Cuisenaire rods. (2017). Mathematics Teaching, 256, 26-27.

Ministerie van Openbaar Onderwijs. (1936). Leerplan en leidraad voor de eerste drie graden der lagere scholen en der oefenklassen toegevoegd aan de normaalscholen en voor de voorbereidende afdelingen der middelbare scholen [Curriculum and instructions for the first three degrees 
of the primary schools and of the training classes added to the teachers' colleges and for the preparatory sections of the secondary schools]. Brussels: Ministerie van Openbaar Onderwijs.

Natalis, Ernest (1954). Matériel de calcul. Didactique et psychologie [Material for calculation. Didactics and psychology]. Moniteur des Instituteurs et des Institutrices Primaires, 78 (7), 97-111.

OEEC. (1961). New thinking in school mathematics. Paris: OEEC.

Papy, Georges (1966). Discours prononcé par le professeur G. Papy, Président du Centre belge de pédagogie de la mathématique [Address by Professor G. Papy, President of the Belgian Centre for Mathematics Pedagogy]. Les Nombres en Couleurs. Bulletin Cuisenaire, 21, 4-5.

Papy, Georges (1968). Minicomputer. Brussels: IVAC.

Papy, Frédérique (1968). Sur le premier enseignement de la mathématique et une méthodologie de la formation continue des enseignants [On the first teaching of mathematics and a methodology for in-service teacher education]. Unpublished doctoral dissertation, Faculté des Sciences, Université libre de Bruxelles, Brussels.

Papy, Frédérique (1970). Papy's minicomputer. Mathematics Teaching, 50, 40-45.

Powell, Arthur B. (2007). Caleb Gattegno (1911-1988): A famous mathematics educator from Africa? Revista Brasileira de História da Matemática, Especial $\mathrm{n}^{\circ}$ 1. Festschrift Ubiratan D'Ambrosio, 199-209.

Roller, Samuel (1964). Georges Cuisenaire, notre ami, bonne année! [Georges Cuisenaire, our friend, happy new year!]. Les Nombres en Couleurs. Bulletin Cuisenaire, 11, 1-3.

Roller, Samuel (1966). Allocution prononcée à l'Athénée d'Ixelles le samedi 5 juin 1965 [Address given at the Athénée d'Ixelles on Saturday June 5, 1965]. Les Nombres en Couleurs. Bulletin Cuisenaire, 21, 1-3.

Rollin, Jean (1971). L'heure Cuisenaire [The Cuisenaire clock]. Brussels, Belgium: Calozet.

Savary, Nicolas (1965). Georges Cuisenaire a l'honneur [Georges Cuisenaire has the honour]. Les Nombres en Couleurs. Bulletin Cuisenaire, 19, 1-7.

Servais, Willy (1959). Les nombres en couleurs [Numbers in colour]. Mathematica \& Paedagogia, 17, 51-64.

Vandendriessche, Louis, Vandendriessche, Simone, Cousin, L., Dumont, Marcel, \& Level, Y. (1967). Les mathématiques modernes à l'école primaire grâce aux "nombres en couleurs » de G. Cuisenaire. Livre de l'élève $n^{\circ} 1$ (cours préparatoire) [Modern mathematics in primary school thanks to G. Cuisenaire's "numbers in colour". Student book n'1 (preparatory course)]. Neuchâtel: Delachaux et Niestlé. 